\title{
Particles in swimming pool filters - Does pH determine the DBP formation?
}

\author{
Hansen, Kamilla Marie Speht; Willach, Sarah; Mosbæk, Hans; Andersen, Henrik Rasmus
}

Published in:

Chemosphere

Link to article, DOI:

10.1016/j.chemosphere.2012.01.003

Publication date:

2012

Link back to DTU Orbit

Citation (APA):

Hansen, K. M. S., Willach, S., Mosbæk, H., \& Andersen, H. R. (2012). Particles in swimming pool filters - Does pH determine the DBP formation? Chemosphere, 87(3), 241-247.

https://doi.org/10.1016/j.chemosphere.2012.01.003

\section{General rights}

Copyright and moral rights for the publications made accessible in the public portal are retained by the authors and/or other copyright owners and it is a condition of accessing publications that users recognise and abide by the legal requirements associated with these rights.

- Users may download and print one copy of any publication from the public portal for the purpose of private study or research.

- You may not further distribute the material or use it for any profit-making activity or commercial gain

- You may freely distribute the URL identifying the publication in the public portal

If you believe that this document breaches copyright please contact us providing details, and we will remove access to the work immediately and investigate your claim. 


\title{
Particles in swimming pool filters - Does $\mathrm{pH}$ determine the DBP formation?
}

\author{
Kamilla M. S. Hansen ${ }^{1}$, Sarah Willach ${ }^{1,2}$, Hans Mosbak ${ }^{1}$, and Henrik R. Andersen ${ }^{1, *}$. \\ ${ }^{1}$ Department of Environmental Engineering, Technical University of Denmark (DTU), Miljoevej, \\ Building 113, 2800 Kgs. Lyngby, Denmark \\ ${ }^{2}$ Department of Chemistry, University of Duisburg-Essen, Germany \\ *Corresponding author: telephone: +45 4525 1583, E-mail: henrik@ ndersen.net
}




\begin{abstract}
The formation was investigated for different groups of disinfection byproducts (DBPs) during chlorination of filter particles from swimming pools at different $\mathrm{pH}$ values and the toxicity was estimated. Specifically, the formation of the DBP group trihalomethanes (THMs), which is regulated in many countries, and the non-regulated haloacetic acids (HAAs) and haloacetonitriles (HANs) were investigated at $6.0 \leq \mathrm{pH} \leq 8.0$, under controlled chlorination conditions. The investigated particles were collected from a hot tub with a drum micro filter. In two series of experiments with either constant initial active or initial free chlorine concentrations the particles were chlorinated at different $\mathrm{pH}$ values in the relevant range for swimming pools. THM and HAA formations were reduced by decreasing $\mathrm{pH}$ while HAN formation increased with decreasing $\mathrm{pH}$. Based on the organic content the relative DBP formation from the particles was higher than previously reported for body fluid analogue and filling water. The genotoxicity and cytotoxicity estimated from formation of DBPs from the treated particle suspension increased with decreasing $\mathrm{pH}$. Among the quantified DBP groups the HANs were responsible for the majority of the toxicity from the measured DBPs.
\end{abstract}

Keywords: Chlorination; swimming pool; pH; particles; DBPs; Genotoxicity

\title{
1 Introduction
}

Swimming pools are used around the world for recreational, rehabilitation and physical activity and therefore it is imperative that the water and air quality are safe for the health of the bathers. Chlorination is by far the most applied method to control pool water quality and to prevent spreading of pathogens from swimmers because of its residual disinfection effect (WHO, 2006). Chlorine exhibits a $\mathrm{pH}$ and temperature dependent-equilibrium between the hypochlorous acid $(\mathrm{HOCl})$ and the hypochlorite ion $\left(\mathrm{OCl}^{-}\right)\left(\mathrm{pK}_{\mathrm{a}, 25^{\circ} \mathrm{C}}=7.5\right)$, with the sum of the two commonly known as free chlorine (White, 1992). $\mathrm{HOCl}$ is the main active species responsible for the disinfection effect of chlorine. Therefore it is crucial to closely monitor and control pool water $\mathrm{pH}$ to ensure disinfection effectiveness (White, 1992). Chlorine reacts with the natural organic matter (NOM) found in the source water and the organic material deposited by the swimmers. A part of the organic material is mineralized (Judd and Bullock, 2003) while the rest cause formation of chlorinated organic compounds commonly known as disinfection by-products (DBPs). Currently, more than 600 different DBPs have been detected in chlorinated drinking water (Richardson, 2011) but the identified compounds only comprise approximately $30-50 \%$ of the total organic halogen (Krasner et al., 2006; Richardson et al., 2007). In a survey of 50 pools from France approximately $50 \%$ of the total organic halogen are covered by the four groups of DBPs: Trihalomethanes (THMs), haloacetic acids (HAAs), haloacetonitriles (HANs), and chloral hydrate (Brunet et al., 2010).

THMs were the first carbon based DBP group to be detected in chlorinated drinking water (Bellar et al., 1974; Rook, 1974) and linked to NOM for their formation. Other DBP groups include HAAs (Heller-Grossman et at., 1993; Cowman and Singer, 1996), HANs (Oliver, 1983), halonitromethanes (Thibaud et al., 1987), and haloketones (Suffet et al., 1976) have later been 
detected in chlorinated drinking water. These organic DBPs have been identified in swimming pool water as well (Richardson et al., 2010), together with inorganic nitrogenous DBPs like trichloramine $\left(\mathrm{NCl}_{3}\right)$ (Hery et al., 1995). The major concern regarding DBP formation in swimming pools is their effect to human health because some are carcinogenic (Richardson et al., 2007) while others are suspected to cause asthma (Thickett et al., 2002; Goodman and Hays, 2008), and irritations to the eyes and mucous membrane (Chiswell and Wildsoet, 1989; Erdinger et al., 1998). Furthermore, a large study on bladder cancer has found an increased risk associated with swimming in pools (Villanueva et al., 2007).

Regulations of DBPs in swimming pool water around the world have focused only on THMs and combined chlorine (chloroamines), which are easily analyzed. However, recent research has shown that other chlorinated molecules such as cyanogen halides, HAAs and HANs (Glauner et al., 2005; Zwiener et al., 2007) are much more relevant DBPs in the pool water since they are directly linked to cancer risk and are generally more toxic than the regulated DBPs. The cyto- and genotoxic potency of HANs is higher than HAAs which is higher than THMs (Plewa et al., 2008). In a recent pool conference proceedings paper, two HANs, dibromoacetonitrile and bromochloroacetonitrile were found to be important contributors to the overall toxicity of pool water (Kramer et al., 2009). In a recent study, seven public pools with different disinfection and source water treatment practices had higher genotoxic potency than their supply water because of DBP formation (Liviac et al., 2010).

One way to limit the formation of some DBPs is to reduce the chlorine concentration as well as the pool water $\mathrm{pH}$ to slightly more acidic conditions, so $\mathrm{HOCl}$ concentration is maintained thus maintaining the disinfection efficiency since $\mathrm{HOCl}$ is a stronger disinfectant than $\mathrm{OCl}^{-}$.

Inspired by the $\mathrm{pH}$ dependency of disinfection efficiency of chlorine (defined by $\mathrm{HOCl}$ concentration) and the German standards use of lower chlorine concentrations $\left(0.3-0.6 \mathrm{mg} \mathrm{L}^{-1}\right)$ combined with lower $\mathrm{pH}(6.5-7.5)$ a Danish full scale study experimentally operated a public indoor swimming pool at $\mathrm{pH} 6.7$ and $0.4 \mathrm{mg}$ chlorine $\mathrm{L}^{-1}$ compared to the traditional $\mathrm{pH} 7.3$ and 1.5 $\mathrm{mg} \mathrm{L}^{-1}$ of chlorine. The study showed a decrease in THM, absorbable organic halogen (AOX) and combined chlorine while microbiological quality was retained (Kristensen et al., 2007). Based on that study it has been officially suggested in Denmark to change the regulations for swimming pools to promote running of the pools at lower $\mathrm{pH}$, specifically changing the lower limit for the $\mathrm{pH}$ from 7.0 to 6.8 , while lowering the $\mathrm{pH}$ even to 6.0 has been discussed. Though this may be beneficial by decreasing the formation of THM, AOX and combined chlorine, a recent study shows that formation of $\mathrm{HAN}$ and $\mathrm{NCl}_{3}$ increases with decreasing $\mathrm{pH}$ (Hansen et al., 2011) when chlorine reacts with an artificial analog of the mixture of soluble compounds that bathers pollute the swimming pool water (known as body fluid analogue, BFA).

Besides the dissolved compounds the swimmers release particles consisting mainly of hair and skin cells. In traditional pool water treatment systems these particles are retained on sand filters, where they are exposed to the chlorinated pool water until they are removed by back flushing the sand filter. Back flushing frequencies depend on the rise in backpressure of the filter and local regulations, but in practice the frequency varies from daily to biweekly. During the exposure to 
chlorinated water the particles are hydrolyzed and react with chlorine which results in DBP formation. THM and HAN formation from hair and skin at $\mathrm{pH} 7$ are reported (Kim et al., 2002) but to our knowledge the $\mathrm{pH}$ effect on the formation of DBPs has not been investigated.

A few swimming pools in Denmark use drum filters based on a weaved microsieve (cutoff 10 or $20 \mu \mathrm{m}$ ) which removes the particles from the pool water fast by washing the filter as the filter cloth turns out of the water stream (See Fig. SM-1 in Supplementary Materials (SM)). This removes the particles from contact with the pool water much faster than traditional sand filters. Depending on the load and pool type backwashing frequencies and thus maximal water contact time for collected particles can be less than 15 min.

In this study particles were collected from a microsieve filter from a hot tub which was used to investigate the effect of $\mathrm{pH}$ on DBP formation from particles which would typically be trapped in the filter. Specifically, the impact of pool water $\mathrm{pH}$ on the formation of 4 THMs, 6 HAAs, 4 HANs, $\mathrm{NCl}_{3}$, trichloronitromethane, dichloropropanone, and trichloropropanone (see Table 1 for the complete list) was investigated at fixed $\mathrm{pH}$ values under controlled chlorination conditions. Further, the measured DBP concentration was used with literature values for toxic potency of each compound to estimate the overall cytotoxicity and genotoxicity of the chlorinated particle suspension at the different $\mathrm{pH}$ levels.

\section{Material and method}

\subsection{Reagents}

All chemicals and standard solutions were analytical grade purchased from Sigma-Aldrich.

\subsection{Analysis of THMs and HANs}

Free chlorine in THM and HAN samples was quenched by adding $200 \mu \mathrm{L}$ of ammonium chloride solution $\left(50 \mathrm{~g} \mathrm{~L}^{-1}\right)$ to $40 \mathrm{~mL}$ borosilicate glass vials before it was filled head-space-free with the sample. The samples were analyzed the same day by Purge and Trap (Velocity XPT Purge and Trap Sample Concentrator, Teledyne Tekmar, with autosampler: AQUATek 70, Teledyne Tekmar) coupled with a GC (HP 6890 Series GC System, Hewlett Packard) with mass spectrometer (5973 Mass selective detector, Hewlett Packard). This method was also used for the detection of trichloronitromethane, dichloropropanone, and trichloropropanone. For more information refer to SM.

\subsection{Analysis of Haloacetic Acids}

For the analysis of the haloacetic acids a modified version of the EPA 552.2 method was used. Sulfuric acid, sodium sulfate, surrogate standard (2-bromobutanoic acid) and methyl-tert-butyl ether (MtBE) was added to the samples and extracted. The MtBE phase was transferred to a test tube and acidified methanol was added. The samples were placed in an oven at $60{ }^{\circ} \mathrm{C}$ for $2 \mathrm{~h}$ to methylate the haloacetic acids and subsequently neutralized by adding saturated sodium bicarbonate solution. The MtBE phase was then transferred to a GC vial and analyzed on a GC (7890A GC System, Agilent 
Technologies) coupled to a mass spectrometer (5975C, Agilent Technologies). Details on the method can be found in the SM.

\subsection{Analysis of Chlorine, Combined Chlorine and Trichloramine}

The residual chlorine and the solution $\mathrm{pH}$ were measured at the beginning and the end of each experiment. The hypochlorite stock solution $(\sim 10 \% \mathrm{w} / \mathrm{w}$, Sigma-Aldrich) and the free and total chlorine of the samples were measured with a photometer (DR 2800, Hach Lange) using the diethyl-p-phenylendiamine method from a cell test kit (LCK 310, Lange).

The trichloramine was measured by the method described by Lützenkirchen and Breuer (2007) and Hery et al. (1995). Trichloramine was stripped from the water by aerating the sample for 20 min and trapping the released trichloramine on a filter impregnated with arsenite $\left(\mathrm{As}_{2} \mathrm{O}_{3}\right)$ which reduced trichloramine to chloride. The filter was subsequently placed in MilliQ water to dissolve the chloride which was measured by ion chromatography (ICS-1500, Dionex). A more detailed description of the method can be found in SM.

\subsection{Samples of particles}

Particles were collected from a drum micro filter on a hot tub in the indoor public swimming pool of Køge Municipality, Zealand, Denmark. The filter collects particles larger than $10 \mu \mathrm{m}$. The hot tub has a hydraulic retention time of 6 min and the filter was flushed every 6 min which results in an average contact time with chlorine for the particles of less than $15 \mathrm{~min}$. The particle suspension from flushing the filter was collected on the $6^{\text {th }}$ of July 2010. Immediately after collection residual chlorine was quenched with sodium sulfite before subsamples were frozen in glass bottles until used for experiments (less than $14 \mathrm{~d}$ ).

In order to scale the dose of particles used in experiments the hydrolysable carbon from the particle suspension was estimated by treating a subsample of particles at $\mathrm{pH} 2$ (phosphoric acid) for $12 \mathrm{~h}$ before the subsample was filtered and DOC was measured with the total organic carbon analyzer (TOC-V WP, Shimadzu) using UV and persulphate for mineralization.

\subsection{DBP formation tests}

The formation of DBPs from particles from swimming pool was investigated by DBP formation tests. Similar test parameters have been used in other studies to investigate $\mathrm{NCl}_{3}$ formation (Schmalz et al., 2011) and THM and HAA formation (Kanan and Karanfil, 2011).

Principally, excess chlorine compared to the dose required to theoretically completely oxidize the $\mathrm{NOM}$ was added to the water. When experiments were made with constant free chlorine $(\mathrm{HOCl}+$ $\mathrm{OCl}^{-}$) concentration the initial concentration of $\mathrm{Cl}_{2}$ was $35 \mathrm{mg} \mathrm{L}^{-1}$. Specifically, at constant free chlorine $\left(35 \mathrm{mg} \mathrm{L}^{-1}\right)$ the $\mathrm{HOCl}$ concentration was $34 \mathrm{mg} \mathrm{L}^{-1}$ at $\mathrm{pH} 6$ and $9.1 \mathrm{mg} \mathrm{L}^{-1}$ as $\mathrm{Cl}_{2}$ at $\mathrm{pH} 8$.

In experiments where the concentration of active chlorine $(\mathrm{HOCl})$ was constant the chlorine was added at a calculated initial concentration of $\mathrm{HOCl}$ of $26.6 \mathrm{mg} \mathrm{L}^{-1}$ by adding hypochlorite adjusted according to the speciation at each given $\mathrm{pH}$ value. Specifically, at constant active chlorine (26.6 $\mathrm{mg} \mathrm{L}^{-1}$ ) the free chlorine concentration was $27 \mathrm{mg} \mathrm{L}^{-1}$ at $\mathrm{pH} 6$ and $102 \mathrm{mg} \mathrm{L}^{-1}$ at $\mathrm{pH} 8$. 
The ratio between the initial $\mathrm{Cl}_{2}$ and $\mathrm{DOC}$ in this formation test is much higher than the ratios between measured $\mathrm{Cl}_{2}$ and DOC in swimming pools. This does not mean that the experimental conditions are unrealistic since most of the DOC in pool water has been in the water a long time and reflects the fraction of carbon added over a long time which is not reactive to chlorine.

\subsection{Experiments performed}

All the chlorination experiments were carried out as batch experiments. The particle suspension was homogenized by shaken it well before taking sample for experiment and was dosed equivalent to $125 \mu \mathrm{g}$ acid dissolved DOC L $\mathrm{L}^{-1}\left(10.4 \mu \mathrm{mol} \mathrm{L} \mathrm{L}^{-1}\right)$ in freshly made reverse osmosis water.

For the investigation of formation of THM, HAN and HAA the diluted particle suspension was buffered with phosphate buffer at $\mathrm{pH}$ 6.0, 6.5, 7.0, 7.5, and 8.0 and the chlorination were applied either as constant initial concentration of free chlorine $\left(\mathrm{HOCl}+\mathrm{OCl}^{-}\right)$or active chlorine $(\mathrm{HOCl})$ as described in the previous section. The experiments were performed in headspace-free borosilicate glass bottles sealed with caps with a PTFE (polytetrafluoroethylen) seal (SCHOTT DURAN) to avoid loss of the volatile compounds. The bottles were kept at $25{ }^{\circ} \mathrm{C}$ for $48 \mathrm{~h}$, and then samples were taken for analysis of THM, HAN, HAA and chlorine residues and for measuring the solution $\mathrm{pH}$. Table 1 contains the compounds analyzed and their abbreviation.

The experiment for trichloramine detection was carried out as headspace-free duplicate in $100 \mathrm{~mL}$ borosilicate glass bottles at $\mathrm{pH} 6.0$ buffered with phosphate buffer. The diluted particle suspension was added $35 \mathrm{mg} \mathrm{L}^{-1}$ free chlorine. To avoid any degradation of $\mathrm{NCl}_{3}$ due to UV-radiation the bottles were wrapped with aluminum-foil and allowed to react for $24 \mathrm{~h}$ at $25^{\circ} \mathrm{C}$.

Table 1. List of investigated compounds and chemical structures.

\begin{tabular}{|c|c|c|c|}
\hline & Compound & Abbreviation & Chemical structure \\
\hline \multirow{4}{*}{ THMs } & Chloroform & TCM & $\mathrm{CHCl}_{3}$ \\
\hline & Bromodichloromethane & $\mathrm{BDCM}$ & $\mathrm{CHBrCl}_{2}$ \\
\hline & Dibromochloromethane & DBCM & $\mathrm{CHBr}_{2} \mathrm{Cl}$ \\
\hline & Bromoform & TBM & $\mathrm{CHBr}_{3}$ \\
\hline \multirow{6}{*}{ HAAs } & Chloroacetic acid & CAA & $\mathrm{CH}_{2} \mathrm{ClCOOH}$ \\
\hline & Bromoacetic acid & BAA & $\mathrm{CH}_{2} \mathrm{BrCOOH}$ \\
\hline & Dichloroacetic acid & DCAA & $\mathrm{CHCl}_{2} \mathrm{COOH}$ \\
\hline & Bromochloroacetic acid & BCAA & $\mathrm{CHBrClCOOH}$ \\
\hline & Dibromoacetic acid & DBAA & $\mathrm{CHBr}_{2} \mathrm{COOH}$ \\
\hline & Trichloroacetic acid & TCAA & $\mathrm{CCl}_{3} \mathrm{COOH}$ \\
\hline \multirow{4}{*}{ HANs } & Dichloroacetonitrile & DCAN & $\mathrm{CHCl}_{2} \mathrm{CN}$ \\
\hline & Bromochloroacetanotile & BCAN & $\mathrm{CHBrClCN}$ \\
\hline & Dibromoacetonitrile & DBAN & $\mathrm{CHBr}_{2} \mathrm{CN}$ \\
\hline & Trichloroacetonitrile & TCAN & $\mathrm{CCl}_{3} \mathrm{CN}$ \\
\hline \multirow{4}{*}{ Others } & Trichloronitromethane & & $\mathrm{CCl}_{3} \mathrm{NO}_{2}$ \\
\hline & Dichloropropanone & & $\mathrm{CHCl}_{2} \mathrm{COCH}_{3}$ \\
\hline & Trichloropropanone & & $\mathrm{CCl}_{3} \mathrm{COCH}_{3}$ \\
\hline & Trichloramine & & $\mathrm{NCl}_{3}$ \\
\hline
\end{tabular}




\section{Calculations}

Based on the measured concentration of the different DBPs, the cyto- and genotoxicity was estimated as the sum of the concentration of each compound divided by its $\mathrm{EC}_{50}$ (Eq. 1).

$$
\sum_{1}^{i} \frac{C_{i}}{E C_{50, i}}
$$

All the $\mathrm{EC}_{50}$ values were used as reported in the literature (Plewa et al., 2002; Muellner et al., 2007; Plewa et al., 2008). These references were chosen because all the investigated compounds were tested in the same assay, except dichloropropanone and trichloropropanone which were not detected in the experiments of this study. The assay used was an in vitro cellular toxicological assays based on Chinese hamster ovary cells and the cytotoxicity was measured as the reduction in cell density while the genotoxicity was measured by single cell gel electrophoresis (Plewa et al., 2002; Muellner et al., 2007; Plewa et al., 2008). The $\mathrm{EC}_{50}$ values used for the estimations are given in Table SM-2.

\section{Results and Discussion}

\subsection{Effect of $\mathrm{pH}$ on DBP formation}

Reaction of chlorine with the collected particles resulted in formation of DBPs. The control experiment with freshly made reverse osmosis water at $\mathrm{pH} 7$ and $35 \mathrm{mg} \mathrm{L}^{-1}$ chlorine resulted in very low concentration of chloroform $\left(0.039 \mu \mathrm{mol} \mathrm{L}^{-1}\left(5.0 \mu \mathrm{g} \mathrm{L}^{-1}\right)\right)$, dichlorocetonitrile (DCAN, 0.0040 $\left.\mu \mathrm{mol} \mathrm{L}{ }^{-1}\left(0.44 \mu \mathrm{g} \mathrm{L}^{-1}\right)\right)$ and trichloracetonitrile $\left(\mathrm{TCAN},<0.016 \mu \mathrm{mol} \mathrm{L}-1\left(2.4 \mu \mathrm{g} \mathrm{L}^{-1}\right)\right)$. These concentrations were negligible compared to the ones obtained in the experiments with particles. The chlorinated organic DBPs: THMs, HAAs, and HANs were detected (Fig. 1). The chlorination approach (constant free versus constant active chlorine concentration) did not have a significant effect on the formation of THMs, HAAs and HANs, except for TCAN at $\mathrm{pH} 8$. At $\mathrm{pH} 8$ a high concentration of chlorine was needed to have $26.6 \mathrm{mg} \mathrm{L}^{-1}$ of active chlorine and that caused high formation of TCAN.

The effect of $\mathrm{pH}$ combined with the effect of the chlorination approaches on the DBP formation differed for the investigated DBP groups. Particularly, the lowest chloroform formation was found at $\mathrm{pH} 6$ and the formation increased with increasing pH-level (Fig. 1a). The same $\mathrm{pH}$ dependency was observed during chlorination of BFA, which simulates sweat and urine contamination from swimmers, (Hansen et al., 2011) as well as drinking water (Liang and Singer, 2003; Bougeard et al., 2008). In these studies the precursor material had different characteristics. The drinking water contains NOM while the BFA includes dissolved organic matter from sweat and urine, and the particles consisting of hair and skin cells. The main differences between the DBP-precursors are that the anthropogenic DBP-precursors (BFA and particles) have higher nitrogen to carbon molar ratio compared to NOM. However, despite the difference in the DBP-precursors they exhibit the same $\mathrm{pH}$ dependency regarding THM formation. 

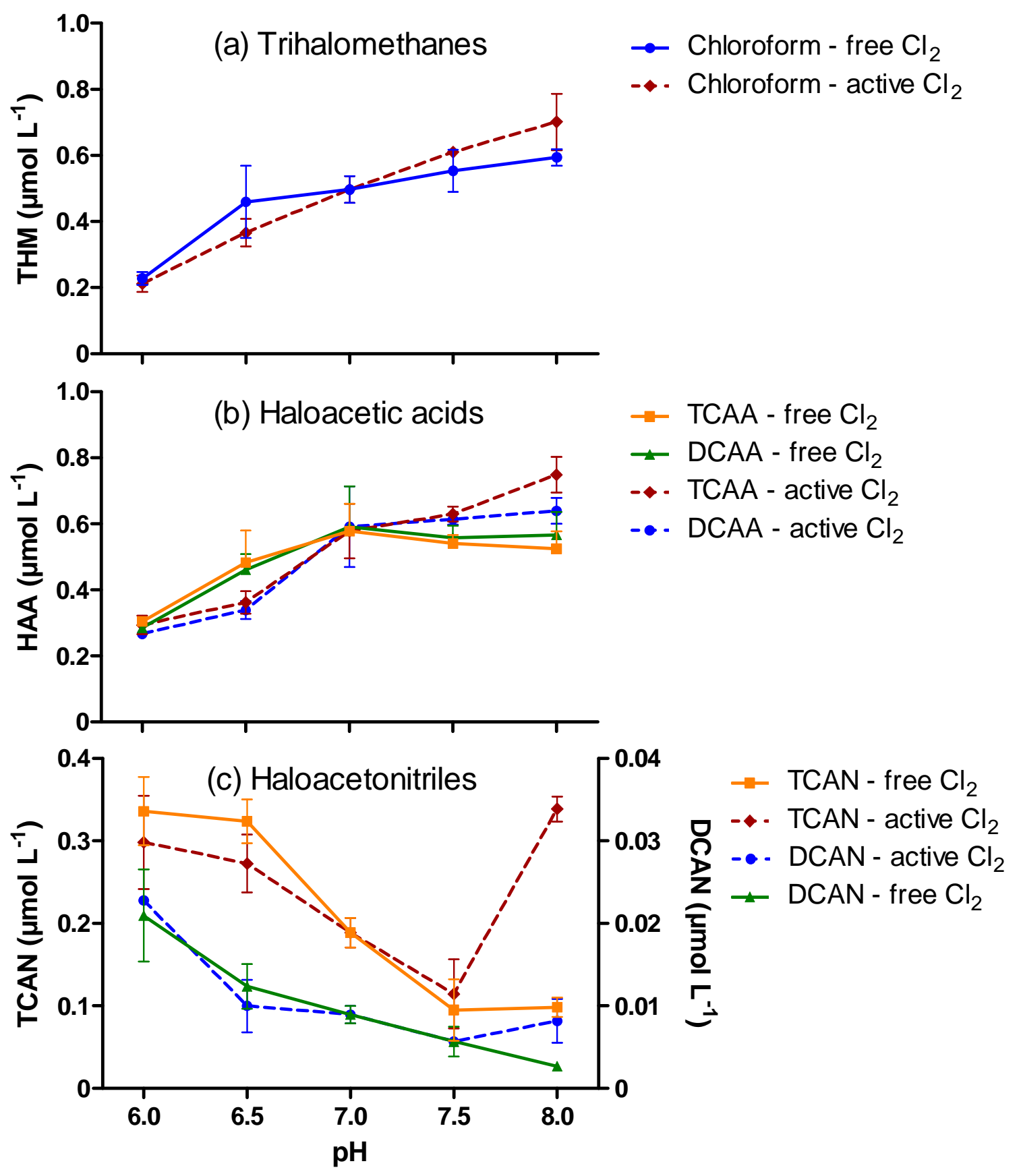

Figure 1. Effect of pH on THM (a), HAA (b) and HAN (c) formation from filter particles with constant free chlorine and active chlorine. Brominated species were not detected. The error bars represent the standard deviation of three replicates. Reaction time $=48 \mathrm{~h}$, temperature $=25^{\circ} \mathrm{C}$ and particle suspension $=125 \mu \mathrm{g}$ DOC L $\mathrm{L}^{-1} .1 \mu \mathrm{mol}$ correspond to $119 \mu \mathrm{g}$ chloroform, $163 \mu \mathrm{g}$ TCAA, $129 \mu \mathrm{g}$ DCAA, $144 \mu \mathrm{g}$ TCAN or $110 \mu \mathrm{g}$ DCAN.

The formation of HAAs was lowest at pH 6 and increased with pH-levels (Fig. 1b). Since there are limited studies on the effect of $\mathrm{pH}$ on DBP formation in swimming pool water our findings were 
compared with studies on chlorination of drinking water. Some studies reported increasing HAA concentration with decreasing pH (Cowman and Singer, 1996; Liang and Singer, 2003) while others found contradictory $\mathrm{pH}$ dependencies for two different types of drinking water (Bougeard et al., 2008). Furthermore, a study on chlorination of BFA observed no pH effect (Hansen et al., 2011). Based on these findings, it can be concluded that the $\mathrm{pH}$ effect on the HAA formation strongly depends on the precursor material.

Generally, TCAN formation was favored over DCAN (Fig. 1c) which was generally formed in approximately 20 times higher concentration. The highest formation of HANs was observed at $\mathrm{pH} 6$ and the formation decreased with increasing $\mathrm{pH}$ for the constant free chlorine experiments and the experiments with constant active chlorine except for TCAN in the latter experiment which increased again from $\mathrm{pH} 7.5$ to 8 . The increase may be due to the high free chlorine concentration needed to obtain constant active chlorine concentration at $\mathrm{pH} 8.0\left(26 \% \mathrm{HOCl}\right.$ and $\left.74 \% \mathrm{OCl}^{-}\right)$and has been observed as well in previous studies (Hansen et al., 2011). HANs are the most toxic DBP group examined in our study (Plewa et al., 2008) and HANs have also been reported to be the DBP group that contributes the most to the toxicity of chlorinated pool water (Kramer et al., 2009). Therefore, in order to limit their formation it is imperative to identify the conditions where HANs are produced. To the best of our knowledge, a recent study was the first to identify the conditions under which they are formed during chlorination of body fluid analogue (Hansen et al., 2011) and the findings were similar to the findings in this study with chlorination of filtered particles.

Previous studies have found that the highest formation of $\mathrm{NCl}_{3}$ occurs at low $\mathrm{pH}$ (Palin, 1950; Schmalz et al., 2011). Therefore $\mathrm{NCl}_{3}$ from particle suspension was initially tested at $\mathrm{pH} 6.0$ only and the formation was found negligible around the limit of quantification for the method $(0.8 \mu \mathrm{mol}$ $\left.\mathrm{L}^{-1}\left(96 \mu \mathrm{g} \mathrm{L}^{-1}\right)\right)$. The experiment with the particles suspension had a total THM level at $0.23 \mu \mathrm{mol}$ $\mathrm{L}^{-1}\left(27 \mu \mathrm{g} \mathrm{L}^{-1}\right.$ as chloroform) which was higher than the BFA study $\left(0.077 \mu \mathrm{mol} \mathrm{L}^{-1}\left(9 \mu \mathrm{g} \mathrm{L} \mathrm{L}^{-1}\right.\right.$ as chloroform)) and in the BFA study the $\mathrm{NCl}_{3}$ formation was $31 \mu \mathrm{mol} \mathrm{L} \mathrm{L}^{-1}\left(3700 \mu \mathrm{g} \mathrm{L}^{-1}\right)$, which is much higher than LOQ $=0.8 \mu \mathrm{mol} \mathrm{L}{ }^{-1}\left(96 \mu \mathrm{g} \mathrm{L}{ }^{-1}\right.$ ) (Hansen et al., 2011). Consequently, $\mathrm{NCl}_{3}$ formation was not investigated for the entire $\mathrm{pH}$ range 6.5-8.0 of this study. Based on our findings it appears that trichloramine is not formed from particles in the traditional sand filter in swimming pool treatment. This fits well with the results in a resent published paper (Schmalz et al., 2011) where urea is found to be the main precursor for $\mathrm{NCl}_{3}$ during an investigation of different amides, amino acids, and amines. Urea is soluble and will not be caught in the filters. The collected hair and skin cells mainly consist of the three amino acids cysteine (17.5\%), serine (11.7\%) and glutamic acid (11.1\%) (McElwee, 2011). Schmalz et al. (2011) found that by reaction with chlorine $95 \%$ of urea was transformed to $\mathrm{NCl}_{3}$ at $\mathrm{pH} 5.9$ but only $19 \%$ of glutamic acid and $15 \%$ of serine was found as $\mathrm{NCl}_{3}$. Cysteine was not investigated, however, like alanine, it is substituent at the alpha-carbon contrary to glycine and cysteine so it is expected to form very little $\mathrm{NCl}_{3}$ like alanine $(5.4 \%$ at $\mathrm{pH}$ 5.9).

In addition to the abovementioned compounds, trichloronitromethane, dichloropropanone, and trichloropropanone were also monitored in all the experiments. However, their formations were too close to the method detection limit (detection limit of trichloronitromethane $6.1 \cdot 10^{-9} \mathrm{M}\left(1.0 \mu \mathrm{g} \mathrm{L}{ }^{-1}\right.$ ), 
dichloropropanone $4.9 \cdot 10^{-9} \mathrm{M}\left(0.6 \mu \mathrm{g} \mathrm{L}^{-1}\right)$, and trichloropropanone $8.3 \cdot 10^{-11} \mathrm{M}\left(0.01 \mu \mathrm{g} \mathrm{L}^{-1}\right)$ and therefore, conclusions on the effects of $\mathrm{pH}$ and chlorination approaches cannot be made.

\subsection{Relative DBP formation}

So far, the load of particles per bather measured as TOC has not been determined and thus it is difficult to compare how much DBPs originate from particles compared to the soluble pollution from one person. Therefore each group of DBPs was normalized to the acid dissolved DOC as $\Sigma$ DBPs/DOC and a comparison of the normalized formation was made (Table 2). At pH 7.0 the HAAs had the highest formation at $9.6 \mu \mathrm{mol}(\mathrm{mg} \mathrm{DOC})^{-1}$, followed by THMs at $4.0 \mu \mathrm{mol}(\mathrm{mg}$ DOC $)^{-1}$ with HANs having the lowest formation at $1.6 \mu \mathrm{mol}\left(\mathrm{mg}\right.$ DOC) ${ }^{-1}$. Kim et al. (2002) have tested DBP formation from hair and skin collected from a 25-yr-old man. However, the results are not directly comparable because they performed their formation experiments in water with high TOC levels which in most cases resulted in higher level of DBP in their control than their experiments.

Table 2. Relative DBP formation at pH 7.0 from different studies.

\begin{tabular}{|c|c|c|c|c|c|}
\hline & $\begin{array}{c}\text { THM } \\
\mu \mathrm{mol}(\mathrm{mg} \mathrm{DOC})^{-1}\end{array}$ & $\begin{array}{c}\text { HAA } \\
\mu \mathrm{mol}(\mathrm{mg} \mathrm{DOC})^{-1}\end{array}$ & $\begin{array}{c}\text { HAN } \\
\mu \mathrm{mol}(\mathrm{mg} \mathrm{DOC})^{-1}\end{array}$ & НАА/ТНМ & HAN/THM \\
\hline Particles & 4.0 & 9.6 & 1.6 & 2.41 & 0.40 \\
\hline BFA $^{\mathbf{a}}$ & 0.077 & 0.27 & 0.025 & 3.48 & 0.33 \\
\hline BFA $^{b}$ & 0.25 & 0.51 & & 2.03 & \\
\hline Filling water ${ }^{\mathbf{b}}$ & 0.62 & 0.26 & & 0.42 & \\
\hline
\end{tabular}

${ }^{\mathrm{a}}$ Hansen et al., $2011{ }^{\mathrm{b}}$ Kanan and Karanfil, 2011

The formation of DBPs from chlorination of the BFA suggested by Judd and Bullock (2003) has previously been investigated. Hansen et al. (2011) reported the formation of DBPs as $0.27 \mu$ mol HAA (mg DOC) ${ }^{-1}, 0.077 \mu \mathrm{mol}$ THM (mg DOC) ${ }^{-1}$ and $0.025 \mu$ mol HAN (mg DOC) ${ }^{-1}$. Kanan and Karanfil (2011) reported with higher chlorine to DOC ratios formation at $0.25 \mu \mathrm{mol}$ THM (mg DOC $)^{-1}$ and $\left.0.51 \mu \mathrm{mol} \mathrm{HAA} \mathrm{(mg} \mathrm{DOC}\right)^{-1}$ for BFA and for the filling water the formation is reported at $0.62 \mu \mathrm{mol}$ THM (mg DOC) ${ }^{-1}$ and $\left.0.26 \mu \mathrm{mol} \mathrm{HAA} \mathrm{(mg} \mathrm{DOC)}\right)^{-1}$. For the particles and the BFA the formation of HAAs was higher than the formation of THM, while the opposite is the case for the filling water. However, it appears that the particles have a higher potential to form DBPs in swimming pool water relative to the organic carbon content than the BFA and the filling water. This suggests that the organic material in the filtered particles creates more DBPs than other types of organic material tested. However, it is also possible that this is due to the fact that chlorine can react with more of the organic material in the particle suspension than is estimated by determining the DOC after hydrolysis at low $\mathrm{pH}$.

When the DBP formation is normalized to the THM formation for each type of organic carbon discussed above, as shown in Table 2, it can be seen that the HAA/THM ratio was between 2 and 3.5 for material of human origin while for the NOM from the filling water the ratio was 0.4. The HANs were only measured in one study besides this and the HAN/THM ratio from chlorination of 
BFA was quite similar at 0.33 compared to 0.40 for particles in this study, which can be explained by the two materials containing similar nitrogen rich molecules mainly based on amino acids.

\subsection{Cytotoxicity and Genotoxicity}

To evaluate the effect of DBP formation on the bathers' health, the cytotoxicity of the chlorinated particle suspension at the different $\mathrm{pH}$ values and chlorination approaches was estimated as described in Sec. 3.

The highest cytotoxicity was found at $\mathrm{pH} 6.0$ and 6.5 in the case with constant free chlorine (Fig. 2a) and at $\mathrm{pH} 6.0$ for constant active chlorine (Fig. 2b). In both cases the estimated cytotoxicity decreased with increasing $\mathrm{pH}$, but for constant active chlorine the toxicity increased again at $\mathrm{pH}$ 8.0. The contribution of THMs to the overall solution toxicity was negligible compared to the other groups. However, the absolute values of THM toxicity increased with increasing $\mathrm{pH}$ which relates to the increasing THM concentration shown in Fig. 1a. Likewise, the HAA and HAN contribution to toxicity were dependent of the solution $\mathrm{pH}$, as were the overall concentrations (Fig. $1 \mathrm{~b}$ and c). The toxicity of the HANs comprise $63-92 \%$ of the total estimated cytotoxicity, which make the HANs the most toxicity relevant group of DBPs measured in this study followed by the HAAs, and with the THMs contributing the least to the toxicity.

Free chlorine
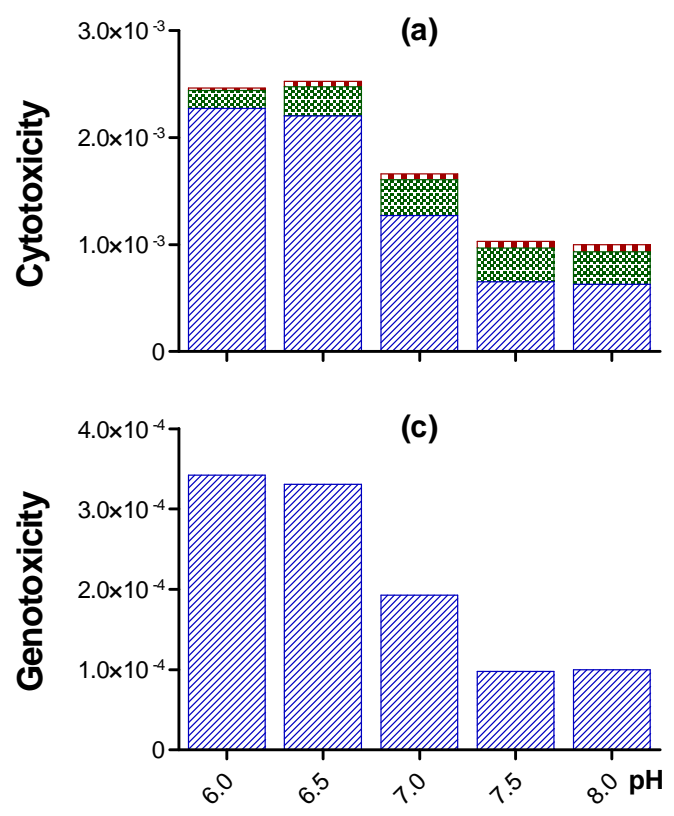

Active chlorine
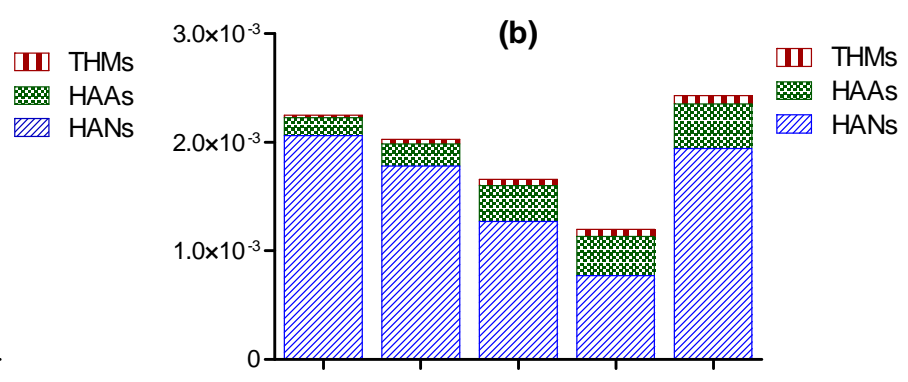

(d)

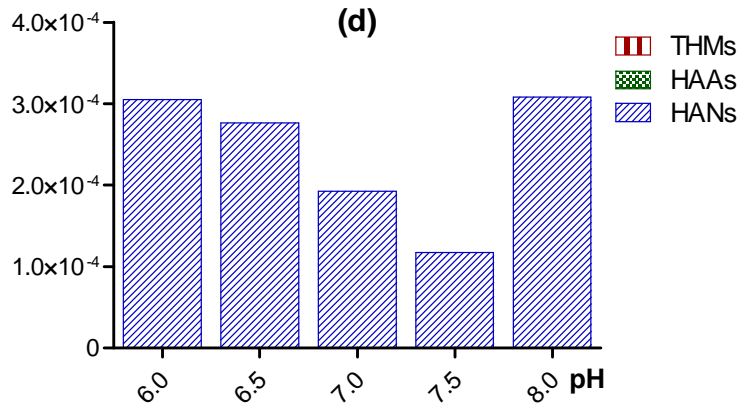

Figure 2. Estimated cytotoxicity (a, b) and genotoxicity (c, d) of chlorinated particle water with constant free and active chlorine, at $6.0 \leq \mathrm{pH} \leq 8.0$.

The genotoxicity of the chlorinated particle suspension in each experiment was estimated in the same way as the cytotoxicity. The genotoxicity follows similar trends as the cytotoxicity. The highest toxicity was found at $\mathrm{pH} 6.0$ with decreasing genotoxicity with increasing $\mathrm{pH}$-levels, except 
for $\mathrm{pH} 8.0$ at constant active chlorine (Fig. 2c and 2d). Contradictory to the cytotoxicity, for the DBPs measured in this study, the HANs are the only contributor to the estimated genotoxicity since chloroform, DCAA, TCAA were not genotoxic in the assay used by Plewa et al. (2002) and Plewa et al. (2008).

Based on the above, the HANs contribute most to the toxicity of the DBPs measured and the group is thus predicted to be an important contributor for the cyto- and genotoxicity of the treated pool water. Similar results have been obtained when chlorinating body fluid analog at different $\mathrm{pH}$ values (Hansen et al., 2011) and was also reported in a preliminary study of real pool water (Kramer et al., 2009).

\section{Conclusions}

This study investigated the effect of $\mathrm{pH}$ and chlorination approach on the formation of three DBP groups: THMs, HAAs and HANs. The $\mathrm{pH}$ affects the formation of each investigated DBP group differently, while there was no real difference between the two chlorination approaches. A decrease in concentration of THMs which is regulated in many countries and the non-regulated HAAs was observed for decreasing $\mathrm{pH}$, while the concentration of the HANs increased. The particles were more reactive to chlorine than body fluid analogue for THMs, HAAs, and HANs and the relative DBP formation was higher.

Furthermore, the cyto- and the genotoxic potency of the chlorinated particle suspension were estimated by calculations. At pH 6.0 the highest cyto- and genotoxicity was found which decreased with increasing solution $\mathrm{pH}$. The HANs are the most significant toxic compounds detected in this study though they are found at low concentration. However, it is not known how much the HANs contribute to the overall mixture toxicity. Based on the above, the $\mathrm{pH}$ level of pool water affects the formation of DBPs from particles in swimming pool filters. Therefore caution is warranted if the $\mathrm{pH}$-level in swimming pool waters can be decreased to levels less than 7.0 in order to reduce the concentration of THMs, since the concentration of the more toxic HANs appear to increase.

\section{Acknowledgements}

The authors thank DTU Environment for funding and the staff at Køge public swimming pool and Henning Hammerich from Rambøll Consulting Engineers for assistance with particle collection. Sinh Hy Nguyen at DTU Environment is acknowledged for technical assistants. Maria Antoniou at DTU Environment is acknowledged for assistance with preparing this manuscript. The work was supported by the Graduate School Urban Water Technology (www.urbanwatertech.dk).

\section{References}

Bellar, T.A., Lichtenberg, J.J., Kroner, R.C., 1974. Occurrence of organohalides in chlorinated drinking waters. J. Am. Water Works Ass. 66, 703-706. 
Bougeard, C.M.M., Janmohamed, I.H.S., Goslan, E.H., Jefferson, B., Watson, J.S., Morgan, G.H., Parsons, S.A., 2008. Parameters affecting haloacetic acid and trihalomethane concentrations in treated UK drinking waters. In: Karanfil T., Krasner S.W., Xie Y. (Eds.), Disinfection ByProducts in Drinking Water: Occurrence, Formation, Health Effects, and Control. American Chemical Society, Washington, DC, pp. 95-108.

Brunet, R., Berne, F., De Laat, J., 2010. Disinfection by-products in chlorinated swimming pool waters. (In French, Sous-produits de chloration dans les eaux de piscines publiques). L'Eau, L'Industrie, Les Nuisances 333, 83-88. http://www.revue-ein.com/article-EIN/2869/Sousproduits_de_chloration_dans_les_eaux_de_piscines_publiques/?string=

Chiswell, B., Wildsoet, C.F., 1989. The causes of eye irritation in swimming pools. Water Sci. Technol. 21 (2), 241-244.

Cowman, G.A., Singer, P.C., 1996. Effect of bromide ion on haloacetic acid speciation resulting from chlorination and chloramination of aquatic humic substances. Environ. Sci. Technol. 30, $16-24$.

Erdinger, L., Kirsch, F., Sonntag, H.G., 1998. Irritating effects of disinfection by-products in swimming pools. Zbl. Hyg. Umweltmed. 200, 491-503.

Glauner, T., Waldmann, P., Frimmel, F.H., Zwiener, C., 2005. Swimming pool water-fractionation and genotoxicological characterization of organic constituents. Water Res. 39, 4494-4502.

Goodman, M., Hays, S, 2008. Asthma and swimming: A meta-analysis. J. Asthma 45, 639-647.

Hansen, K.M.S., Willach, S., Antoniou, M. G., Mosbæk, H., Albrechtsen, H.-J., Andersen, H. R., 2011. Effect of selection of $\mathrm{pH}$ in swimming pools on formation of chlorination byproducts. Proceedings of Fourth international conference swimming pool and spa, Porto, Portugal.

Heller-Grossman, L., Manka, J., Limoni-Relis, B., Rebhun, M., 1993. Formation and distribution of haloacetic acids, THM and TOX in chlorination of bromide-rich lake water. Water Res. 27, 1323-1331.

Hery, M., Hecht, G., Gerber, J.M., Gendre, J.C., Hubert, G., Rebuffaud, J., 1995. Exposure to chloramines in the atmosphere of indoor swimming pools. Ann. Occup. Hyg. 39, 427-439.

Judd, S.J., Bullock, G., 2003. The fate of chlorine and organic materials in swimming pools, Chemosphere 51, 869-879. 
Kanan, A., Karanfil, T., 2011. Formation of disinfection by-products in indoor swimming pool water: The contribution from filling water natural organic matter and swimmer body fluids. Water Res. 45, 926-932.

Kim, H., Shim, J., Lee, S., 2002. Formation of disinfection by-products in chlorinated swimming pool water. Chemosphere 46, 123-130.

Kramer, M., Hübner, I., Rörden, O., Schmidt, C.K., 2009. Haloacetonitriles - another importent group of disinfection byproducts in swimming pool water. Proceedings of Swimming Pool \& Spa International Conference, London, UK.

Krasner, S.W., Weinberg, H.S., Richardson, S.D., Pastor, S.J., Chinn, R., Sclimenti, M.J., Onstad, G.D., Thruston, A.D., 2006. Occurrence of a new generation of disinfection byproducts. Environ. Sci. Technol. 40, 7175-7185.

Kristensen, G.H., Klausen, M.M., Janning, K., 2007. Experimental Operation of a Warm Water Pool in Glasaxe Swimming Pool at Low Chlorine Level and pH (In Danish: Forsøgsdrift af varmtvandsbassin i Gladsaxe Svømmehal ved lavt indhold af frit klor og reduceret $\mathrm{pH}$ ). June 2007. Report from DHI, Denmark. www.dhigroup.com.

Liang, L., Singer, P.C., 2003. Factors influencing the formation and relative distribution of haloacetic acids and trihalomethanes in drinking water. Environ. Sci. Technol. 37, 2920-2928.

Liviac, D., Wagner, E.D., Mitch, W.A., Altonji, M.J., Plewa, M.J., 2010. Genotoxicity of water concentrates from recreational pools after various disinfection methods. Environ. Sci. Technol. 44, 3527-3532.

Lützenkirchen, C., Breuer, D., 2006. Trichloramine, no. 8623 (In German: Stickstofftrichlorid (Kennzahl 8623)). In: BGIA - Institut für Arbeitsschutz (Eds.). BGIA - Arbeitsmappe Messung von Gefahrstoffen. Erich Schmidt Verlag, Berlin.

McElwee, K.J., 2011, http://www.keratin.com/aa/aa012.shtml, accessed June 15th, 2011.

Muellner, M.G., Wagner, E.D., McCalla, K., Richardson, S.D., Woo, Y.T., Plewa, M.J., 2007. Haloacetonitriles vs. regulated haloacetic acids: Are nitrogen-containing DBPs more toxic? Environ. Sci. Technol. 41, 645-651.

Oliver, B.G., 1983. Dihaloacetonitriles in drinking-water - algae and fulvic-acid as precursors. Environ. Sci. Technol. 17, 80-83.

Palin, A.T., 1950. Chemical aspects of swimming bath treatment, the baths service: J. Nat. Ass.Bath Supt. 9, 12-20. 
Plewa, M.J., Kargalioglu, Y., Vankerk, D., Minear, R.A., Wagner, E.D., 2002. Mammalian cell cytotoxicity and genotoxicity analysis of drinking water disinfection by-products. Environ. Mol. Mutagen. 40, 134-142.

Plewa, M.J., Wagner, E.D., Muellner, M.G., Hsu, K.M., Richardson, S.D., 2008. Comparative mammalian cell toxicity of N-DBPs and C-DBPs. In: Karanfil T., Krasner S.W., Xie Y. (Eds.), Disinfection By-Products in Drinking Water: Occurrence, Formation, Health Effects, and Control. American Chemical Society, Washington, DC, pp. 36-50.

Richardson, S.D. 2011. Disinfection By-Products: Formation and Occurrence of Drinking Water, In: Nriagu, J.O. (Ed.), The Encyclopedia of Environmental Health, Vol. 2. Elsevier, Burlington, pp. 110-136.

Richardson, S.D., DeMarini, D.M., Kogevinas, M., Fernandez, P., Marco, E., Lourencetti, C., Ballesté, C., Heederik, D., Meliefste, K., McKague, A.B., Marcos, R., Font-Ribera, L., Grimalt, J.O., Villanueva, C.M., 2010. What's in the pool? A comprehensive identification of disinfection by-products and assessment of mutagenicity of chlorinated and brominated swimming pool water. Environ. Health. Persp. 118, 1523-1530.

Richardson, S.D., Plewa, M.J., Wagner, E.D., Schoeny, R., DeMarini, D.M., 2007. Occurrence, genotoxicity, and carcinogenicity of regulated and emerging disinfection by-products in drinking water: A review and roadmap for research. Mutat. Res.-Rev. Mutat. 636, 178-242.

Rook, J.J., 1974. Formation of haloforms during chlorination of natural waters. Water Treat. Exam. $23,478-482$.

Schmalz, C., Frimmel, F.H., Zwiener, C., 2011. Trichloramine in swimming pools - Formation and mass transfer. Water Res. 45, 2681-2690.

Suffet, I.H., Brenner, L., Silver, B., 1976. Identification of 1,1,1-trichloroacetone (1,1,1trochloropropanone) in 2 drinking waters - known precursor in haloform reaction. Environ. Sci. Technol. 10, 1273-1275.

Thibaud, H., De Laat, J., Merlet, N., Dore, M., 1987. Chloropicrin formation in aqueous solution effect of nitrites on precursors formation during the oxidation of organic compounds. Water Res. 21, 813-822.

Thickett, K.M., McCoach, J.S., Gerber, J.M., Sadhra, S., Burge, P.S., 2002. Occupational asthma caused by chloramines in indoor swimming-pool air. Eur. Respir. J. 19, 827-832.

Villanueva, C.M., Cantor, K.P., Grimalt, J.O., Malats, N., Silverman, D., Tardon, A., GarciaClosas, R., Serra, C., Carrato, A., Castaño-Vinyals, G., Marcos, R., Rothman, N., Real, F.X., Dosemeci, M., Kogevinas, M., 2007. Bladder cancer and exposure to water disinfection by- 
Hansen et al. 2012. Accepted for publication in Chemoshpere

products through ingestion, bathing, showering, and swimming in pools. Am. J. Epidemiol. $165,148-156$.

White, G.C., 1992. Handbook of Chlorination and Alternative Disinfectants. Van Nostrand Reinhold, New York.

WHO, 2006. Guidelines for Safe Recreational Water Environments. Volume 2, Swimming Pools and Similar Environments. World Health Organization,WHO Press, Geneva, Switzerland.

Zwiener, C., Richardson, S.D., DeMarini, D.M., Grummt, T., Glauner, T., Frimmel, F.H., 2007. Drowning in disinfection byproducts?. Assessing swimming pool water. Environ. Sci. Technol. 41, 363-372. 


\section{Supplementary Materials}

\section{Particles in swimming pool filters - Does $\mathrm{pH}$ determine the DBP formation?}

Kamilla M. S. Hansen ${ }^{1}$, Sarah Willach ${ }^{1,2}$, Hans Mosbck ${ }^{1}$, and Henrik R. Andersen ${ }^{1, *}$.

${ }^{1}$ Department of Environmental Engineering, Technical University of Denmark (DTU), Miljoevej, Building 113, 2800 Kgs. Lyngby, Denmark

${ }^{2}$ Department of Chemistry, University of Duisburg - Essen, Germany

*Corresponding author: telephone+45 4525 1583, e-mail Henrik@ndersen.net

Number of pages: 6

Content:

System description of the hot tub (SM page 2)

Detailed description of the analyses

Analysis of trihalomethans and haloacetonitriles (SM page 2)

Analysis of haloacetic acids (SM page 3)

Analysis of trichloroamine (SM page 5)

$\mathrm{EC}_{50}$ value of cyto- and genotoxicity (SM page 5) 


\section{System description of the hot tub}

The volume of the hot tub is $3 \mathrm{~m}^{3}$ with hydraulic flow of $30 \mathrm{~m}^{3} / \mathrm{h}$ which results in a hydraulic retention time of $6 \mathrm{~min}$. This design follows the regulation in Denmark. The chlorine level is 1.2 $\mathrm{mg} / \mathrm{L}$. The drum filter collects particle larger than $10 \mu \mathrm{m}$.

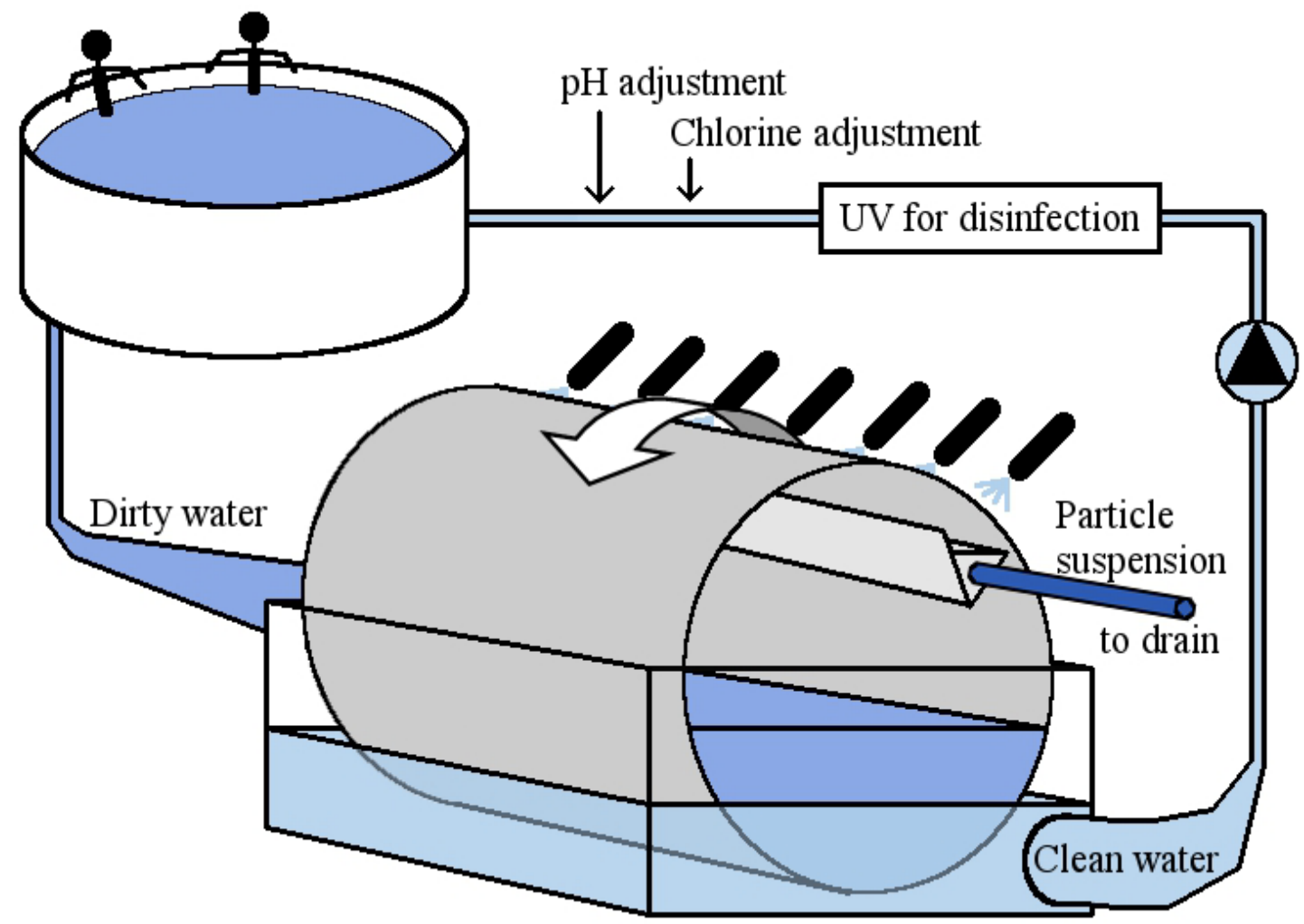

Figure SM-1. Schematic of water treatment of the hot tub.

The drum filter rotates when the resistance to water flow through the filter is so high that the water level inside the filter raises and thus fresh filter cloth is put into the water while dirty filter cloth is back flushed. The flushing occurs $100-150$ times a day and with $12 \mathrm{~h}$ of opening it results in a back flush approximately every $6 \mathrm{~min}$. The particle suspension from the back flush is led to the drain.

\section{Detailed experimental section}

\subsection{Analysis of THMs and HANs}

Free chlorine in THM and HAN samples was quenched by adding $200 \mu \mathrm{L}$ ammonium chloride solution $(50 \mathrm{~g} / \mathrm{L})$ to $40 \mathrm{~mL}$ borosilicate glass vials before it was filled head-space-free with the sample and were analyzed the same day. An autosampler (AQUATek 70, Teledyne Tekmar) with a $5 \mathrm{~mL}$ loop was used to transfer the samples to the purge cell (Velocity XPT Purge and Trap Sample Concentrator, Teledyne Tekmar). The sample was purged for 11 minutes by bubbling nitrogen with a flow rate of $44 \mathrm{~mL} / \mathrm{min}$. The compound was adsorbed on a trap, VOCARB 3000, Telmark ${ }^{\circledR}$. The sample was desorbed for 3 minutes at $250^{\circ} \mathrm{C}$ from the trap. Simultaneously, with desorption from the trap, the GC (HP 6890 Series GC System, Hewlett Packard) was started with a flow rate of helium at $2.5 \mathrm{~mL} / \mathrm{min}$, which was set to $1 \mathrm{~mL} / \mathrm{min}$ after the 3 minutes. The analysis was performed 
in split mode with a ratio of $3: 1$. To clean the trap and minimize carryover it was baked at $260{ }^{\circ} \mathrm{C}$ with a flow rate of $200 \mathrm{~mL} / \mathrm{min}$ for 5 minutes. The compounds were separated with a fused silica capillary column (30.0 m x $0.25 \mathrm{~mm}$ i.D., $1.5 \mu \mathrm{m}$ film thickness; VOCOL, Supelco). The initial temperature of the oven was $45^{\circ} \mathrm{C}$ for the first 3 minutes and then it increased with a rate of by 25 ${ }^{\circ} \mathrm{C} / \mathrm{min}$ until it reached $230{ }^{\circ} \mathrm{C}$. The compounds were detected with a mass spectrometer $(5973$ Mass selective detector, Hewlett Packard) set in SIM mode. The ions monitored during SIM mode is given in Table SM-1.

\subsubsection{Preparation of standards}

For each run a new calibration curve was prepared, with a range of $1-100 \mu \mathrm{g} / \mathrm{L}$ and if found necessary it was extended to $0.1-200 \mu \mathrm{g} / \mathrm{L}$. Standard solutions for HANs were made from the EPA 551B Halogenated Volatiles Mix $(2000 \mu \mathrm{g} / \mathrm{mL})$ standard mixture dissolved in acetone. The THMs standard solution $(2000 \mu \mathrm{g} / \mathrm{mL})$ was prepared by mixing the 4 individual THMs in methanol, based on their density.

Table SM-1. Detection and quantification limit for the trihalomethanes, haloacetonitriles, halopropanones and trichloronitromethane based on their quantifier and qualifier ions.

\begin{tabular}{|c|c|c|c|c|}
\hline Compound & $\begin{array}{l}\text { Quantifier } \\
\text { ion }(\mathrm{m} / \mathrm{z})\end{array}$ & $\begin{array}{l}\text { Qualifier } \\
\text { ions }(\mathrm{m} / \mathrm{z})\end{array}$ & $\begin{array}{l}\text { Detection } \\
\text { limit }(\mathrm{mol} / \mathrm{l})\end{array}$ & $\begin{array}{l}\text { Quantification } \\
\text { limit (mol/l) }\end{array}$ \\
\hline Trichloromethan (TCM) & 83 & 85,47 & $4.2 \cdot 10^{-9}$ & $1.4 \cdot 10^{-8}$ \\
\hline $\begin{array}{l}\text { Bromodichloromethane } \\
(\mathrm{BDCM})\end{array}$ & 129 & 83,85 & $1.7 \cdot 10^{-9}$ & $5.8 \cdot 10^{-9}$ \\
\hline $\begin{array}{l}\text { Dibromochloromethane } \\
\text { (DBCM) }\end{array}$ & 129 & 127,131 & $5.0 \cdot 10^{-9}$ & $1.7 \cdot 10^{-8}$ \\
\hline Tribromomethane (TBM) & 173 & $\begin{array}{l}171, \quad 175, \\
252\end{array}$ & $5.6 \cdot 10^{-10}$ & $7.6 \cdot 10^{-10}$ \\
\hline Dichloroacetonitrile (DCAN) & 74 & 76,84 & $7.7 \cdot 10^{-10}$ & $2.6 \cdot 10^{-9}$ \\
\hline $\begin{array}{l}\text { Bromochloroacetanotile } \\
\text { (BCAN) }\end{array}$ & 76 & 74,155 & $1.9 \cdot 10^{-8(*)}$ & $1.9 \cdot 10^{-8(*)}$ \\
\hline $\begin{array}{l}\text { Dibromoacetonitrile (DBAN) } \\
\text { Trichloroacetonitrile (TCAN) }\end{array}$ & $\begin{array}{l}120 \\
108\end{array}$ & $\begin{array}{l}118,199 \\
110,73,82\end{array}$ & $\begin{array}{l}1.1 \cdot 10^{-8} \\
1.6 \cdot 10^{-8}\end{array}$ & $\begin{array}{l}1.5 \cdot 10^{-8} \\
1.6 \cdot 10^{-8}\end{array}$ \\
\hline $\begin{array}{l}\text { Trichloronitromethane } \\
\text { (TCnitro) }\end{array}$ & 117 & $119,121,82$ & $6.1 \cdot 10^{-9(*)}$ & $6.1 \cdot 10^{-9(*)}$ \\
\hline Dichloropropanone (DCprop) & 63 & 83 & $4.9 \cdot 10^{-9}$ & $1.6 \cdot 10^{-8}$ \\
\hline Trichloropropanone (TCprop) & 125 & 127,97 & $8.3 \cdot 10^{-11}$ & $8.3 \cdot 10^{-10}$ \\
\hline
\end{tabular}

${ }^{(*)}$ Detection and quantification limit are given based on the lowest detected standard.

\subsection{Analysis of haloacetic acids}

For the analysis of the haloacetic acids a modified version of the EPA 552.2 method was used. To quench the residual chlorine of the samples $200 \mu \mathrm{L}$ of $50 \mathrm{~g} / \mathrm{mL}$ sodium sulfite were filled into each P\&T vial, following by the addition of $30 \mathrm{~mL}$ of sample. The analysis was subdivided into four main steps: extraction, methylation (i.e., derivatization), neutralization and finally analysis in the GC-MS.

In order to extract the haloacetic acids, a stepwise acidification of the water sample with $3 \mathrm{~mL}$ of concentrated $\mathrm{H}_{2} \mathrm{SO}_{4}$, was performed in order to avoid sudden changes in the solution temperature. In addition, the samples were cooled-down in an ice bath. $100 \mu \mathrm{L}$ of the surrogate standard, 2bromobutanoic acid $(0.1 \mathrm{~g} / \mathrm{L}$ in methanol) and approximately $9.5 \mathrm{~g}$ of sodium sulfate were added to 
the samples. Following this, the P\&T vials were sealed with a teflon-lined screw cap and were hand-shaken in order to make a saturated salt solution. Finally, $2 \mathrm{~mL}$ of MtBE were added to the samples. The samples were then sealed with the caps and placed on a mechanical shaking table for another $30 \mathrm{~min}$.

Following that, time was given, so the two solution phases (water vs. MtBE phase) were separated, and the MtBE phase was transferred into a conical tube. The control derivatization standard was prepared by adding $15 \mu \mathrm{L}$ of the EPA 552.2 standard mix and $100 \mu \mathrm{L}$ of surrogate standard to $1.5 \mathrm{~mL}$ of MtBE. $0.5 \mathrm{~mL}$ of acidified methanol $\left(10 \% \mathrm{H}_{2} \mathrm{SO}_{4}\right)$ was then added to each conical tube. The tubes were tightly sealed with a Teflon-lined screw cap and placed into the oven at $60{ }^{\circ} \mathrm{C}$ for $2 \mathrm{~h}$.

The tubes were left to cool-down before the caps were removed. The samples were neutralized by adding $2 \mathrm{~mL}$ of saturated sodium bicarbonate $\left(50 \mathrm{~g} \mathrm{NaHCO}_{3}\right.$ in $400 \mathrm{~mL}$ deionized water). After the neutralization the MtBE phase was partly transferred to a $\mathrm{GC}$ vial, sealed with a silicone/PTFE screw cap and analyzed at the same day.

The samples were analyzed in a GC-MS (7890 A GC System and 5975 C VLMSD, Agilent Technologies). The compounds were separated in a fused silica capillary column (30 $\mathrm{m} \times 0.25$ i.D. $1.5 \mu \mathrm{m}$ film thickness; VOCOL, Supelco). The carrier gas was helium with a flow rate of 1.3 $\mathrm{mL} / \mathrm{min}$. The starting temperature was $45{ }^{\circ} \mathrm{C}$ for $1 \mathrm{~min}$ and then it increased with a rate of 20 ${ }^{\circ} \mathrm{C} / \mathrm{min}$ until $140{ }^{\circ} \mathrm{C}$ were reached. Then the temperature rate was reduced to $10{ }^{\circ} \mathrm{C} / \mathrm{min}$ until 155 ${ }^{\circ} \mathrm{C}$. The third ramp was set at $5{ }^{\circ} \mathrm{C} / \mathrm{min}$ until $170{ }^{\circ} \mathrm{C}$ were reached, followed by a rate of $15^{\circ} \mathrm{C} / \mathrm{min}$ until $190{ }^{\circ} \mathrm{C}$. Finally a rate of $40^{\circ} \mathrm{C} / \mathrm{min}$ was used to reach $230^{\circ} \mathrm{C}$, which was held for $2 \mathrm{~min}$.

\subsubsection{Preparation of standards}

For each run a new calibration curve was prepared, with a range of $2-100 \mu \mathrm{g} / \mathrm{L}$ and if found necessary it was extended to $200 \mu \mathrm{g} / \mathrm{L}$. Standard solutions were made from EPA 552.2 Halogenated Acetic Acids Mix ( $2000 \mu \mathrm{g} / \mathrm{mL}$ each component in methyl tert-butyl ether, Supelco). The standards were treated like the samples i.e. extracted, derivatized, neutralized and analyzed with the GC-MS.

Table SM-2. Detection and quantification limit of haloacetic acids based on the quantifier and qualifier ions.

\begin{tabular}{lccccc}
\hline Compound & & $\begin{array}{c}\text { Quantifier ion } \\
(\mathrm{m} / \mathrm{z})\end{array}$ & $\begin{array}{c}\text { Qualifier } \\
\text { ions }(\mathrm{m} / \mathrm{z})\end{array}$ & $\begin{array}{c}\text { Detection limit } \\
(\mathrm{mol} / \mathrm{L})\end{array}$ & $\begin{array}{c}\text { Quantification limit } \\
(\mathrm{mol} / \mathrm{L})\end{array}$ \\
\hline $\begin{array}{l}\text { Chloroacetic } \\
\text { (CAA) }\end{array}$ & acid & 108 & 79,77 & $1.1 \cdot 10^{-7}(*)$ & $1.1 \cdot 10^{-7}(*)$ \\
$\begin{array}{l}\text { Bromoacetic } \\
\text { (BAA) }\end{array}$ & acid & 93 & 121 & $3.6 \cdot 10^{-8(*)}$ & $3.6 \cdot 10^{-8(*)}$ \\
$\begin{array}{l}\text { Dichloroacetic } \\
\text { (DCAA) }\end{array}$ & acid & 83 & 85 & $3.0 \cdot 10^{-9}$ & $9.0 \cdot 10^{-9}$ \\
$\begin{array}{l}\text { Bromochloroacetic } \\
\text { acid (BCAA) }\end{array}$ & 129 & 127 & $1.6 \cdot 10^{-9}$ & $4.8 \cdot 10^{-9}$ \\
$\begin{array}{l}\text { Dibromoacetic } \\
\text { (DBAA) }\end{array}$ & 173 & 171,175 & $1.1 \cdot 10^{-10}$ & $3.2 \cdot 10^{-10}$ \\
$\begin{array}{l}\text { Trichloroacetic } \\
\text { (TCAA) }\end{array}$ & acid & 82 & 84,59 & $1.5 \cdot 10^{-8}$ & $4.5 \cdot 10^{-8}$ \\
$\begin{array}{l}\text { Surrogate standard } \\
\text { (*) Detection and quantification limit are given based on the lowest detected standard. }\end{array}$
\end{tabular}




\subsection{Analysis of trichloramine}

The filter for the trichloroamine analysis consisted of two 37-mm quartz fiber filters (with one of them being a back-up filter) impregnated with $500 \mu \mathrm{L}$ of a solution of arsenic (III) oxide $(8 \mathrm{~g} / \mathrm{L}$ $\left.\mathrm{As}_{2} \mathrm{O}_{3}\right)$, sodium carbonate $\left(106 \mathrm{~g} / \mathrm{L} \mathrm{Na} \mathrm{CO}_{3}\right)$ and glycerol $\left(40 \mathrm{~g} / \mathrm{L} \mathrm{C}_{3} \mathrm{H}_{8} \mathrm{O}_{3}\right)$. The two filters were placed in a sampling cassette separated by polypropylene supporting pad and in front of the filter a tube with impregnated silica gel ( $1.25 \mathrm{~g}$ sulfamic acid $/ 50 \mathrm{~g}$ silica gel) was placed to prevent airborne water droplets of chloride, monochloramine and dichloramine from being included in the sample. After sampling, the impregnated filters were desorbed in $10 \mathrm{~mL}$ Milli-Q water, sonicated for 15 $\mathrm{min}$, and left to stand alone for $30 \mathrm{~min}$ before filtering them with a syringe filter $(0.45 \mu \mathrm{m}$ nylon membrane syringe filter, PALL Life Sciences). The chloride concentration was measured by ion chromatography (ICS-1500, Dionex).

\section{$2.4 E_{50}$ value of cyto- and genotoxicity}

The $\mathrm{EC}_{50}$ value of cyto- and genotoxicity used for the estimation of sample toxicity are given in Table SM-3.

Table SM-3. The $\mathrm{EC}_{50}$ values for cyto- and genotoxicity taken from Plewa et al. (2002), Muellner et al. (2007) and Plewa et al. (2008).

\begin{tabular}{|c|c|c|c|}
\hline & & $\begin{array}{c}\text { Cytotoxicity } \mathrm{EC}_{50} \\
(\mathrm{~mol} / \mathrm{L})\end{array}$ & $\begin{array}{c}\text { Genotoxicity } \mathrm{EC}_{50} \\
(\mathrm{~mol} / \mathrm{L})\end{array}$ \\
\hline \multirow{4}{*}{ THM } & $\begin{array}{l}\text { Chloroform } \\
\text { (TCM) }\end{array}$ & $9.1 \cdot 10^{-3}$ & $*$ \\
\hline & $\begin{array}{l}\text { Bromodichloromethane } \\
\text { (BDCM) }\end{array}$ & $9.1 \cdot 10^{-3}$ & $*$ \\
\hline & $\begin{array}{l}\text { Dibromochloromethane } \\
(\mathrm{DBCM})\end{array}$ & $5.2 \cdot 10^{-3}$ & $*$ \\
\hline & Bromoform (TBM) & $4.0 \cdot 10^{-3}$ & $*$ \\
\hline \multirow{4}{*}{ HAN } & $\begin{array}{l}\text { Dichloroacetonitrile } \\
\text { (DCAN) }\end{array}$ & $5.8 \cdot 10^{-5}$ & $2.8 \cdot 10^{-3}$ \\
\hline & $\begin{array}{l}\text { Trichloroacetonitrile } \\
\text { (TCAN) }\end{array}$ & $1.7 \cdot 10^{-4}$ & $1.0 \cdot 10^{-3}$ \\
\hline & $\begin{array}{l}\text { Bromochloroacetanotile } \\
\text { (BCAN) }\end{array}$ & $8.4 \cdot 10^{-6}$ & $3.2 \cdot 10^{-4}$ \\
\hline & $\begin{array}{l}\text { Dibromoacetonitrile } \\
\text { (DBAN) }\end{array}$ & $2.9 \cdot 10^{-6}$ & $3.0 \cdot 10^{-5}$ \\
\hline \multirow{6}{*}{ HAA } & $\begin{array}{l}\text { Chloroacetic acid } \\
\text { (CAA) }\end{array}$ & $9.0 \cdot 10^{-4}$ & $4.1 \cdot 10^{-4}$ \\
\hline & $\begin{array}{l}\text { Bromoacetic } \\
\text { (BAA) }\end{array}$ & $9.8 \cdot 10^{-6}$ & $1.6 \cdot 10^{-5}$ \\
\hline & $\begin{array}{l}\text { Dichloroacetic } \\
\text { (DCAA) }\end{array}$ & $7.2 \cdot 10^{-3}$ & $*$ \\
\hline & $\begin{array}{l}\text { Trichloroacetic acid } \\
\text { (TCAA) }\end{array}$ & $2.3 \cdot 10^{-3}$ & $*$ \\
\hline & $\begin{array}{l}\text { Bromochloroacetic acid } \\
\text { (BCAA) }\end{array}$ & $8.4 \cdot 10^{-4}$ & $3.7 \cdot 10^{-3}$ \\
\hline & $\begin{array}{l}\text { Dibromoacetic acid } \\
\text { (DBAA) }\end{array}$ & $5.2 \cdot 10^{-4}$ & $1.7 \cdot 10^{-3}$ \\
\hline
\end{tabular}




\begin{tabular}{ll}
\hline $\begin{array}{l}\text { Trichloronitromethane } \\
\text { (TCnitro) }\end{array}$ & $5.2 \cdot 10^{-4}$ \\
* The compounds were not found genotoxic in the assay used.
\end{tabular}

* The compounds were not found genotoxic in the assay used.

Muellner, M.G., Wagner, E.D., McCalla, K., Richardson, S.D., Woo, Y.T., Plewa, M.J., 2007. Haloacetonitriles vs. regulated haloacetic acids: Are nitrogen-containing DBPs more toxic?. Environ. Sci. Technol. 41, pp. 645-651.

Plewa, M.J., Kargalioglu, Y., Vankerk, D., Minear, R.A., Wagner, E.D., 2002. Mammalian cell cytotoxicity and genotoxicity analysis of drinking water disinfection by-products. Environ. Mol. Mutagen. 40, pp. 134-142.

Plewa, M.J., Wagner, E.D., Muellner, M.G., Hsu, K.M., Richardson, S.D., 2008. Comparative Mammalian Cell Toxicity of N-DBPs and C-DBPs. In: Karanfil T., Krasner S.W., Xie Y. (Eds.). Disinfection By-Products in Drinking Water: Occurrence, Formation, Health Effects, and Control. American Chemical Society, Washington, DC, pp. 36-50. 